\title{
Effect of Saliva from Cystic Fibrosis Patients and from Normal Subjects on Red Blood Cell Sodium Transport
}

\author{
P. M. GRINWALD ${ }^{(12)}$ AND M. B. SEGAL \\ Sherrington School of Physiology, St. Thomas's Hospital Medical School, London, England
}

\begin{abstract}
Summary
Saliva, whether taken from patients with cystic fibrosis or from normal subjects, caused an increase in red blood cell $\mathbf{N a}^{+}$ efflux (in the presence or absence of ouabain) of 19-29\% as compared with non-saliva controls. However, there was no significant difference between the effects of cystic fibrosis saliva and normal saliva.
\end{abstract}

\section{Speculation}

Saliva, and possibly other body fluids as well, contain substances which influence $\mathrm{Na}^{+}$transport across cell membranes, and which are, as yet, uncharacterized. Further investigation of such substances may be relevant to the transport abnormality of cystic fibrosis.

The raised $\mathrm{Na}^{+}$concentrations of sweat and saliva in patients with cystic fibrosis (CF) are an important diagnostic feature of this disease (2), and may be closely related to its pathogenetic basis. The abnormality may be due to a humoral factor in CF secretions which inhibits $\mathrm{Na}^{+}$transport, as suggested by the finding that $\mathrm{Na}^{+}$reabsorption from the rat parotid duct is inhibited when CF saliva or sweat is introduced into the duct (7). A similar inhibition of $\mathrm{Na}^{+}$reabsorption was found when $\mathrm{CF}$ secretions were introduced into sweat glands of normal humans in vivo (5).

The effects of CF secretions on $\mathrm{Na}^{+}$transport have also been investigated using red blood cell systems. Taussig et al. (9) found no difference in the $\mathrm{Na}^{+}$efflux or influx of normal red cells exposed to CF saliva as compared with normal saliva, although comparison with non-saliva control medium was not included. Duffy et al. (3), however, found that saliva, whether from normal subjects or CF patients, accelerated $\mathrm{Na}^{+}$influx in normal red cells, but found no difference between CF patients and control subjects.

It is necessary to consider, however, that $\mathrm{Na}^{+}$transport across the red cell membrane is mediated by several distinct processes, which include passive permeation and possibly more than one type of active transport (4). It is not known which, if any, of these processes will be affected by a humoral factor in CF saliva. Accordingly, it is not immediately obvious which parameter of $\mathrm{Na}^{+}$transport should be measured in looking for its effect on the red cell.

For guidance as to which is an appropriate parameter to test, it is reasonable to refer to the $\mathrm{Na}^{+}$transport abnormalities which have been found in the red cells of CF patients themselves. Balfe et al. (1) found that ouabain-sensitive and ouabaininsensitive $\mathrm{Na}^{+}$efflux rates were reduced in $\mathrm{CF}$ red cells. Lapey et al. (6) found a reduction in ouabain-insensitive $\mathrm{Na}^{+}$efflux in red cells from males and postpubertal females with $\mathrm{CF}$, but did not find abnormal ouabain-sensitive efflux.
These results suggest that ouabain-insensitive $\mathrm{Na}^{+}$efflux may reflect the influence of a $\mathrm{CF}$ factor more closely than either the total $\mathrm{Na}^{+}$efflux or the $\mathrm{Na}^{+}$influx, measured in previous studies. We have given particular attention to the ouabain-insensitive efflux, after a preliminary study of CF red cells to confirm that this parameter is an appropriate choice.

\section{METHODS}

Normal subjects were Caucasians of either sex, aged 20-34 years, with no personal or family history of $C F$, who were not taking any medication. The CF group was comprised of Caucasian patients of either sex, aged 16-32 years, with clinical and radiologic findings and sweat tests typical of $\mathrm{CF}$; all had received treatment, including pancreatic supplements and antibiotics. The informed consent of all subjects was obtained.

\section{MEASUREMENT OF NA ${ }^{+}$EFFLUX}

Fresh heparinized venous blood was centrifuged at $3000 \times g$ for $5 \mathrm{~min}$, plasma and buffy coat were aspirated, and the red cells were washed three times with isotonic $\mathrm{NaCl}$. The red cells were preincubated for $3 \mathrm{hr}$ at $37^{\circ}$ in a solution containing $\mathrm{NaCl}$ $120 \mathrm{mM}, \mathrm{KCl} 10 \mathrm{mM}$, dextrose $28 \mathrm{mM}$, and Tris- $\mathrm{Cl}$ buffer 20 $\mathrm{mM}$ ( pH 7.4 at $37^{\circ}$ ), to which $25 \mu \mathrm{Ci}^{22} \mathrm{Na}^{+}$had been added. After preincubation, the cells were washed six times with isotonic $\mathrm{NaCl}$ and added to incubation medium prewarmed to $37^{\circ}$ at a hematocrit of approximately $2 \%$. The incubation medium contained $\mathrm{NaCl} 120 \mathrm{mM}, \mathrm{KCl} 10 \mathrm{mM}$, dextrose 11.1 $\mathrm{mM}$, Tris- $\mathrm{Cl}$ buffer $20 \mathrm{mM}$ (pH 7.4 at $\left.37^{\circ}\right)$, and ouabain, where indicated, $0.1 \mathrm{mM}$.

At 0 and $60 \mathrm{~min}$, samples were centrifuged for $3 \mathrm{~min}$ at 3000 $\times g$ and a sample of supernatant fluid was weighed and taken for determination of radioactivity and of optical density at 420 $\mathrm{nm}$. At some time during the incubation, a weighed sample of cell suspension was taken for determination of radioactivity and of optical density at $420 \mathrm{~nm}$ after hemolysis by dilution in distilled water. A Panax 160 crystal scintillation counter was used for measurement of radioactivity, and a Unicam SP600 spectrophotometer for optical density determination.

Efflux experiments were carried out on CF red cells and control red cells simultaneously, and measurements were made in duplicate. Sodium efflux was expressed as a rate constant, $k$, using the equation (8):

$$
k t=-\ln \frac{1-\left(\mathrm{Na}_{\mathrm{s}}^{*} / \mathrm{Na}_{\mathrm{h}}^{*}\right)}{1-\text { fractional hemolysis }}
$$

where $\mathrm{Na}_{\mathrm{s}}^{*}=$ the activity of the supernatant in counts $\mathrm{ml}^{-1}$ $\min ^{-1}, \mathrm{Na}_{\mathrm{h}}^{*}=$ the activity of the hemolyzed sample, and $\mathrm{t}$ is the incubation time. This formulation is accurate at low hemotocrit $(<0.3 \%)$. However, for the present experimental conditions, the error incurred at $2 \%$ hematocrit is small $(2-3 \%)$. 


\section{MEASUREMENT OF NA ${ }^{+}$INFLUX}

After washing as described above, the red cells were suspended in incubation medium as used for efflux experiments, except that $\mathrm{KCl}, 7.5 \mathrm{mM}$, instead of ouabain, was used, at a hemotocrit of about $10 \%$. Then $2.5 \mu \mathrm{Ci}^{22} \mathrm{Na}^{+}$were added and the suspension was incubated at $37^{\circ}$ for $1 \mathrm{hr}$. At the end of the incubation period, the suspension was centrifuged and $50 \mu \mathrm{l}$ supernatant fluid were taken for counting. The cells were washed three times with isotonic $\mathrm{MgCl}_{2}$ to remove external ${ }^{22} \mathrm{Na}^{+}$and then resuspended at a hematocrit of about $30 \%$. The hematocrit was measured in triplicate. Next $1.0 \mathrm{ml}$ of the red cell suspension was transferred to counting tubes. The influx rate was expressed as the proportion of supernatant counts which entered the cells per hour.

\section{PREPARATION OF SALIVA}

Mixed mouth saliva was collected in polythene containers and used within $6 \mathrm{hr}$. The saliva was centrifuged to remove particulate material and the supernatant was adjusted to isotonicity either by dialysis or by adding $\mathrm{NaCl}$. $\mathrm{KCl}$, dextrose, and Tris-Cl buffer ( $\mathrm{pH} 7.4$ ) were then added as isotonic solutions to give concentrations of $10 \mathrm{mM}, 11.1 \mathrm{mM}$, and $20 \mathrm{mM}$, respectively. Ouabain was added where indicated at $0.1 \mathrm{mM}$.

Control media (without saliva) were prepared from aliquots of isotonic $\mathrm{NaCl}$ by similar additions. The samples were then used as incubation media for measurement of $\mathrm{Na}^{+}$efflux for normal red cells.

\section{RESULTS}

CF red cells were found to show a significant decrease in the ouabain-insensitive fraction of $\mathrm{Na}^{+}$efflux (Table 1). Total $\mathrm{Na}^{+}$ efflux and ouabain-sensitive $\mathrm{Na}^{+}$efflux were not significantly different from normal. Influx of $\mathrm{Na}^{+}$appeared to be normal.

Table 2 shows that saliva, whether from normal subjects or from CF patients, produced an increase of $\mathrm{Na}^{+}$transport in red cells, as compared with the non-saliva control medium. Both ouabain-insensitive and total $\mathrm{Na}^{+}$efflux were affected; there was, however, no significant difference between the effects of normal saliva and of CF saliva. When the red cells were washed after brief exposure to saliva (normal or $\mathrm{CF}$ ), ouabain-insensitive efflux was normal, indicating that the salivary constituent

Table $1 . \mathrm{Na}^{+}$transport of normal and $\mathrm{CF}$ red cells ${ }^{1}$

\begin{tabular}{lcc}
\hline & Normal & CF \\
\hline $\begin{array}{l}\text { Ouabain-insensitive } \\
\text { efflux }\end{array}$ & $0.084 \pm 0.014(10)$ & $0.055 \pm 0.022^{2}(10)$ \\
$\begin{array}{l}\text { Ouabain-sensitive } \\
\text { efflux }\end{array}$ & $0.245 \pm 0.073(10)$ & $0.247 \pm 0.057(10)$ \\
$\begin{array}{l}\text { Total efflux } \\
\text { Influx }\end{array}$ & $0.329 \pm 0.068(10)$ & $0.302 \pm 0.053(10)$ \\
& $0.0108 \pm 0.0012(12)$ & $0.0101 \pm 0.0014(12)$ \\
\hline
\end{tabular}

${ }^{1}$ Data are expressed as rate constants (per hour), means $\pm S D$, with number of determinations shown in parentheses.

${ }^{2}$ Significantly different from normal group $(P<0.01)$. responsible for the transport effect was not firmly bound to the cell.

\section{DISCUSSION}

The results shown in Table 1 confirm previous reports that ouabain-insensitive $\mathrm{Na}^{+}$efflux is reduced in CF red cells. No significant difference was found between males and females in this study. Since all patients in this series were postpubertal, the observation (6) that prepubertal females fail to show the transport abnormality was not tested. Although the observed transport abnormality may be due to the disease process itself, the possibility that it may merely reflect therapy (e.g., drug intake) has not been excluded.

In view of the normal $\mathrm{Na}^{+}$content of $\mathrm{CF}$ red cells $(1,6)$, it has been pointed out that reduced efflux should be balanced by a reduced $\mathrm{Na}^{+}$influx (1). The expected reduction in influx, however, is small in relation to overall influx, and would be relatively difficult to demonstrate in the presence of random variation. Presumably for the same reason, the total $\mathrm{Na}^{+}$efflux is not significantly abnormal, even though a small component of efflux (the ouabain-insensitive fraction) is consistently reduced. There is, however, no satisfactory explanation for the inconsistencies between various studies regarding ouabain-sensitive efflux.

From these results, the ouabain-insensitive fraction of $\mathrm{Na}^{+}$ efflux appears to be more satisfactory than other parameters as a marker of CF abnormality in red cells. Accordingly, this parameter was measured in normal red cells exposed to $\mathrm{CF}$ saliva and to normal saliva. The effect on total $\mathrm{Na}^{+}$efflux was also measured for comparison with previous reports.

Table 2 shows that saliva (normal or CF) alters $\mathrm{Na}^{+}$transport rate. This nonspecific effect of saliva appears to be similar to the nonspecific increase found for $\mathrm{Na}^{+}$influx by Duffy $e t$ al . (3). It is due to a nondialyzable component of saliva, the nature of which is obscure. The effect could not be reproduced by addition of bovine serum albumen ( $5 \%$, two experiments), human immunoglobulin ( $2.5 \%$, two experiments), or bradykinin $(15 \mathrm{mg} /$ liter, two experiments) to control media.

It is unlikely that contamination from the dialysis membrane could be responsible, since four samples of saliva which were prepared without dialysis in this series gave similar results to those which were dialyzed; and because control experiments in which incubation medium was exposed to dialysis differed by only $5 \%$ from the effect of incubation medium which had not been dialyzed. Furthermore, the suggestion that the transport effect is intrinsic to saliva is apparently strengthened by the discovery of a similar effect $(21-26 \%$ increase) when normal red cells were tested with autologous blood serum in the same way (two experiments).

It remained possible that the "nonspecific" effect of saliva on $\mathrm{Na}^{+}$transport, with its relatively large size and wide random variation, might be obscuring a "specific" effect of CF saliva. A simple attempt to separate these possibilities was made. It was evident that the transport-accelerating effect of saliva on red cells was easily removed by washing. The behavior of the CF factor, however, as described $(5,7)$, implies that it is firmly

Table 2. $\mathrm{Na}^{+}$efflux of normal red cells in normal saliva and in $\mathrm{CF}$ saliva ${ }^{1}$

\begin{tabular}{|c|c|c|c|c|c|c|}
\hline & \multicolumn{3}{|c|}{ Normal saliva } & \multicolumn{3}{|c|}{ CF saliva } \\
\hline & Mean \pm SD & (n) & $P$ & Mean \pm SD & $(\mathrm{n})$ & $P$ \\
\hline Ouabain-insensitive $\mathrm{Na}^{+}$efflux & $1.19 \pm 0.20$ & (12) & $<0.01$ & $1.29 \pm 0.27$ & (7) & $<0.05$ \\
\hline Total $\mathrm{Na}^{+}$efflux & $1.20 \pm 0.08$ & (10) & $<0.01$ & $1.28 \pm 0.21$ & (7) & $<0.02$ \\
\hline Ouabain-insensitive $\mathrm{Na}^{+}$efflux (after washing) & $1.02 \pm 0.10$ & (8) & & $1.02 \pm 0.07$ & (6) & \\
\hline
\end{tabular}

'Data are expressed as the ratio efflux in saliva/efflux in non-saliva control. The salivary sample and non-saliva control were matched for inorganic constituents and glucose (see "Methods") and red cells from the same blood sample were used in both media simultaneously. The saliva groups for which $P$ values are quoted were significantly different from non-saliva controls. There was no significant difference between the effects of CF saliva groups and normal saliva groups. 
bound to the membrane (in that it resists washing out by the normal flow of secretions). A firmly bound effect was therefore sought by exposing normal red cells to saliva for $5 \mathrm{~min}$, and then washing, before measuring ouabain-insensitive efflux. Table 2 shows that there was no difference between cells exposed to saliva and then washed, and cells not exposed to saliva. No firmly bound factor was demonstrated.

The significance of humoral substances affecting membrane transport remains to be clarified. There does not appear to be any known hormone, for example, which could easily explain the above effect of saliva, whereas simple physical or physicochemical factors would seem to be excluded by the experimental controls. Modification of the cell membrane by uncharacterized circulating or secreted factors may have a bearing on transport processes in general, and possibly on the disturbance of CF in particular. However, the red cell model, as used in this study, has not confirmed that such a mechanism is important in CF.

\section{CONCLUSION}

In a preliminary study, the red blood cells of patients with cystic fibrosis were found to show decreased ouabain-insensitive $\mathrm{Na}^{+}$efflux. The ouabain-sensitive $\mathrm{Na}^{+}$efflux, total $\mathrm{Na}^{+}$efflux, and $\mathrm{Na}^{+}$influx were found to be normal. This information was used to guide the choice of transport parameters in the main study. The effect of cystic fibrosis saliva on normal red cells was not significantly different from that of control saliva, but both

Copyright (C) 1978 International Pediatric Research Foundation, Inc 0031-3998/78/0012-0001\$02.00/0

normal saliva and cystic fibrosis saliva appear to contain a substance which accelerates $\mathrm{Na}^{+}$transport in the red cell

\section{REFERENCES AND NOTES}

1. Balfe, J. W., Cole, C., and Welt, L. G.: Red cell transport defect in patients with cystic fibrosis and in their parents. Science, 162: 689 (1968)

2. Di Sant'Agnese, P. A., and Talamo, R. C.: Pathogenesis and pathophysiology of cystic fibrosis of the pancreas. New Engl. J. Med., 277: 1344 (1967).

3. Duffy, M. J., and Schwarz, V.: Cystic fibrosis and membrane transport Lancet, ii: 136 (1972)

4. Hoffman, J. F., and Kregenow, F. M.: The characterization of new energy dependent cation transport processes in red blood cells. Ann. N. Y. Acad Sci., 137: 566 (1966)

5. Kaiser, D., Drack, E., and Rossi, E.: Effect of cystic fibrosis sweat on sodium transport by the normal sweat gland. Lancet, $i: 1003(1970)$

6. Lapey, A., and Gardner, J. D.: Abnormal erythrocyte sodium transport in cystic fibrosis of the pancreas. Pediat. Res., 5: 446 (1971).

7. Mangos, J. A., McSherry, N. R., and Benke, P. J.: A sodium transport inhibitory factor in the saliva of patients with cystic fibrosis of the pancreas. Pediat. Res., 1: 436 (1967).

8. Sachs, J. R., and Welt, L. G.: The concentration dependence of active potassium transport in the human red blood cell. J. Clin. Invest., 46: 65 (1967).

9. Taussig, L. M., and Gardner, J. D.: Effects of saliva and plasma from cystic fibrosis patients on membrane transport. Lancet, $i$ : 1367 (1972).

10. The authors thank Dr. J. C. Batten, Brompter Hospital, London, for his interest in this work and for permission to study some of his patients.

11. Financial support was provided by the Cystic Fibrosis Research Trust.

12. Requests for reprints should be addressed to: P. M. Grinwald, M.D. Sherrington School of Physiology, St. Thomas's Hospital Medical School, Lambeth Palace Road, London, SE1 7EH (England)

13. Received for publication October 22,1976

14. Accepted for publication April 12, 1977.

Pediat. Res. 12: 3-6 (1978)

Kidney

low birth weight infants myoinositol

renal function

\title{
Myoinositol in Human Neonates: Serum Concentrations and Renal Handling
}

\author{
L. M. LEWIN, S. MELMED ${ }^{(18)}$ J. H. PASSWELL, Y. YANNAI, M. BRISH, S. ORDA, H. BOICHIS \\ AND $H$. BANK \\ Department of Chemical Pathology, Sackler School of Medicine, Tel-Aviv University, and Departments of \\ Medicine and Pediatrics, Chaim Sheba Medical Centre, Tel Hashomer, Israel
}

\section{Summary}

Free myoinositol (henceforth called inositol) levels were measured in cord blood from newborns, as well as in sera from lealthy infants during the first 6 months of life. Renal excretion f inositol by a group of premature infants during their first 2 nonths of life was also studied. Inositol was measured by nicrobiologic assay, using an inositol-requiring yeast, Sacchaomyces carlsbergensis. Inositol concentration in pooled cord iamples of full term normal newborns was $25 \pm 5.3 \mu \mathrm{g} / \mathrm{ml}$. These levels dropped progressively, reaching adult levels (6.9 $\mathrm{\imath g} / \mathrm{ml}$ ) by the eighth week of life. Mean concentration of nositol in cord blood of premature neonates was $30 \mu \mathrm{g} / \mathrm{ml}$.

In premature infants, the inositol content in the urine was lways higher than that of the blood; the average urine concenration was $198 \mu \mathrm{g} / \mathrm{ml}$. Inositol clearance values of premature nfants ranged from $0.10-0.79 \mathrm{ml} / \mathrm{min}$ and averaged $0.34 \mathrm{ml} /$ nin, and were thus lower than the mean inositol clearances of nonuremic normal adults $(2.8 \mathrm{ml} / \mathrm{min})$. The total amounts of inositol excreted per day by the premature infants were considerably higher than the amounts ingested. The blood inositol concentrations in infants in this study are similar to those found in adults with impaired renal function.

The inositol status of the neonate appears to be determined by a balance between the two factors which tend to increase the amount of inositol available, that is, biosynthesis of inositol and ingestion with the formula; and the two factors which decrease the blood level, i.e., kidney maturation with resultant increased inositol clearance and, possibly, renal enzymatic catabolism of inositol.

\section{Speculation}

The rat kidney regulates blood inositol concentration via catabolism by an inositol oxidase. Impaired renal function in man is accompanied by raised serum levels of inositol, as well 